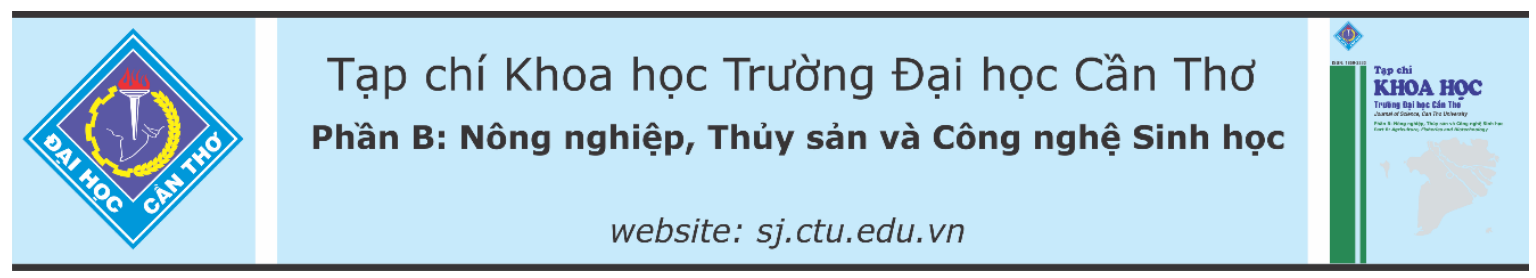

DOI:10.22144/ctu.jvn.2021.023

\title{
HIỆU QUẢ SỬ DỤNG NƯớC MUỐI BIỂN NUÔI SINH KHỐI Artemia TRONG HỆ THỐNG BIOFLOC
}

\author{
Nguyễn Thị Hồng Vân*, Nguyễn Văn Hòa và Huỳnh Thanh Tới \\ Khoa Thủy sản, Truò̀ng Đại học Cần Tho' \\ *Người chịu trách nhiệm về bài viết: Nguyến Thị HồngVân (email: nthvan@ctu.edu.vn)
}

\section{Thông tin chung:}

Ngày nhận bài: 06/08/2020

Ngày nhận bài sưa: 03/11/2020

Ngày duyệt đăng: 27/02/2021

\section{Title:}

Use of crude sea salt in outdoor Artemia biomass culture with biofloc technology

\section{Tù khóa:}

Artemia, biofloc, nuớc muối biển, năng suất sinh khối

\section{Keywords:}

Artemia, bioflocs, biomass production, sea salt medium

\section{ABSTRACT}

In this study, Artemia was cultured in seawater and sea-salt medium with and without biofloc application. The two-factorial experiment produced 4 treatments and there were 3 replicates for each. Artemia was reared in 60 L plastic tanks, containing $40 \mathrm{~L}$ culture medium with a density of 500 nauplii/L, salinity $30 \%$ and lasting for 20 days. In the first two days after stock, Artemia was fed with fresh Chaetoceros algae, and after that till the end of experiment, formulated feed was used as daily food. In biofloc treatments, the C/N ratios were regulated by adding molasses into the Artemia culture medium based on TAN concentration from the $5^{\text {th }}$ day. Results from experiment showed that survival rate, growth rate were more or less similar between the treatments after the $7^{\text {th }}$ day. Fecundity and harvested biomass were influenced by the biofloc application, but the reproduction mode was affected by both experimental factors, and Artemia tend to produce cysts in biofloc combined with seawater (79\%). The biomass collected in biofloc tanks was significantly higher than that in normal culture $(3.52 \mathrm{~g} / \mathrm{L} v \mathrm{~s}$. $3.24 \mathrm{~g} / \mathrm{L} ; p<0.05)$, but it was similar between seawater and sea salt medium (3.30 $\mathrm{g} / \mathrm{L}$ vs. $3.45 \mathrm{~g} / \mathrm{L}$ ). Moreover, the biofloc application also saved $20 \%$ of water exchange and $14 \%$ of feed compared to normal culture, and using of sea salt instead of seawater not only decreases about $46 \%$ in biomass cost, but also gives an initiative to the culturists according to their needs.

\section{TÓM TẮT}

Trong thí nghiệm này, Artemia được nuôi bằng nước biển và nước muối với hai phuơng thức có và không có ứng dụng biofloc, kết hơp của hai nhân tố này cho ra tổ hợp gồm 4 nghiệm thức (NT)với ba lần lạp lại cho mỗi NT. Artemia được nuôi trong các bể nhựa 60 L chía 40 L nuớc nuôi, mật độ 500 nauplii/L, độ mặn $30 \%$ và đurợc theo dôi trong 20 ngày. Trong hai ngày đầu, Artemia được cho ăn tảo twooi Chaetoceros sau đó thay thế bằng thức ăn cho Artemia. Đối với các NT ưng dụng biofloc, rỉ đường được thêm vào bể nuôi tù̀ ngày thứ 5 và tuần tụ bổ sung sau đó theo hàm lượng TAN trong nuớc. Kết quả cho thấy tỷ lệ sống, tăng trường tuoong tư giũua các NT sau ngày nuôi thứ 7. Sức sinh sản và sinh khối thu bị ảnh hưởng bởi ứng dụng biofloc và Artemia có khuynh huớng sinh trứng (79\%) khi nuôi ở nước biển có biofloc. Các NT biofloc có luợng sinh khối thu cao hon nuôi bình thường $(3,52 \mathrm{~g} / \mathrm{L}$ so với $3,24 \mathrm{~g} / \mathrm{L} ; \mathrm{p}<0,05)$ nhung lại tương đương giữa nuớc biển và mước muối $(3,30 \mathrm{~g} / \mathrm{L}$ so với $3,45 \mathrm{~g} / \mathrm{L})$. Thêm vào đó, ứng dụng biofloc tiết kiệm được $20 \%$ nuớc thay và $14 \%$ thức ăn so với nuôi bình thuờng còn sử dụng nước muối làm giảm $46 \%$ giá thành sinh khối và tạo thế chủ động cho người nuôi. 


\section{1. ĐẶT VẤN ĐỀ}

Artemia là thức ăn tươi sống có giá trị dinh dưỡng cao và đã được sử dụng phổ biến trong nuôi trồng thủy sản. Artemia giai đoạn trưởng thành chứa hàm lượng protein cao $(50-60 \%)$, rất giàu acid béo thiết yếu, vitamin, kích dục tố và sắc tố, do đó chúng được chọn làm thức ăn nuôi vỗ tôm, cá bố mẹ (Légeret al., 1986; Nguyễn Văn Hòa và ctv., 2007). Thời gian gần đây, nuôi sinh khối Artemia bắt đầu được quan tâm nhiều do Artemia là thức ăn tốt cho ương nuôi cá, tôm nước ngọt và mặn (Nguyễn Thị Hồng Vân và $c t v$., 2010; Nguyễn Thị Ngọc Anh, 2011). Tuy nhiên, việc sản xuất Artemia thường chỉ diễn ra ở nơi có độ mặn cao như ruộng muối và việc sản xuất còn mang tính mùa vụ (chỉ nuôi được trong mùa khô trong khi đa số con giống được sản xuất vào mùa mưa). Do vậy, muốn việc chủ động đối tượng này thì nuôi sinh khối trên bể kết hợp trong các trại sản xuất giống là rất cần thiết. Ở các trại giống tôm, cá xa biển, nước ót có độ mặn 80-90 \% được sử dụng phổ biến để nuôi sinh khối Artemia với giá rất cao (khoảng 400-450 ngàn/ $/ \mathrm{m}^{3}$ ) làm cho chi phí con giống cũng tăng lên. Để hạn chế yếu điểm này trên cơ sở tận dụng đặc điểm của Artemia là loài rộng muối, có thể sống và tồn tại ở nhiều thủy vực muối khắc nghiệt có tính chất hóa học khác nhau (Van Stappen, 2002), việc thay thế môi trường nuôi nước biển (nước ót) bằng muối biển cho nuôi sinh khối Artemia đã được thử nghiệm. Van and Toi (2019) cho thấy việc thay thế nước biển bằng nước muối không làm ảnh hưởng đến tỷ lệ sống và tăng trưởng của Artemia. Thêm vào đó, ứng dụng biofloc (một phức hợp gồm vi khuẩn dị dưỡng, nấm và tảo) trong nuôi trồng thủy sản gần đây với các nguồn carbon rẻ tiền nhằm giảm lượng thức ăn sử dụng, tăng cường sự thân thiện với môi trường có rất nhiều triển vọng cho việc áp dụng nuôi đại trà (Trần Ngọc Hải và $c t v ., 2016$; Lê Quốc Việt và ctv., 2015; 2017). Ở Artemia, một số nghiên cứu gần đây cho thấy vi khuẩn có thể được sử dụng như nguồn thức ăn thích hợp bổ sung cho Artemia nhờ tính ăn lọc không chọn lựa của Artemia, đặc biệt khi việc cung cấp tảo không đáp ứng đủ thức ăn cho quần thể Artemia và với tỷ lệ $\mathrm{C}: \mathrm{N}$ trong bể nuôi tương đương từ 5-10 (Toi et al., 2013; Huỳnh Thanh Tới và Nguyễn Thị Hồng Vân, 2017) cho thấy lượng sinh khối tăng lên so với nuôi trong môi trường bình thường. Tuy vậy, việc ứng dụng này chưa được thử nghiệm ở quy mô lớn hơn để đánh giá hiệu quả và khả năng ứng dụng khi nuôi sinh khối đại trà cho nên rất cần được kiểm chứng trước khi đưa ra khuyến cáo cho người nuôi. Việc sử dụng nước muối và ứng dụng công nghệ biofloc trong nuôi sinh khối Artemia đạt hiệu quả cao sẽ góp phần đơn giản hóa quy trình nuôi, chủ động được nguồn thức ăn Artemia trong các trại giống từ quy mô nhỏ đến quy mô lớn mà không phải phụ thuộc vào nguồn nước biển.

\section{VÂT LIÊU VÀ PHƯƠNG PHÁP NGHIẾN CÚU}

\subsection{Vật liệu nghiên cứu}

Trứng bào xác Artemia Vĩnh Châu thuộc Khoa Thủy sản Trường Đại học Cần Thơ được sử dụng trong thí nghiệm.

Nguồn nước mặn (nước ót): dùng nước ót (80\%) thu từ Vĩnh Châu pha với nước máy để có độ mặn $30 \%$ sử dụng cho các lô đối chứng. Nước mặn được xử lý bằng chlorine, sục khí liên tục trong 48 giờ, sau đó dùng bộ test kiểm tra lượng Chlorine trong nước, nếu còn tồn dư thì tiếp tục sục khí và dùng Thiosulfatnatri để trung hòa cho tới khi không còn Chlorine.

Nguồn nước muối: muối biển (muối hột trắng) thu từ ruộng muối Vĩnh Châu pha với nước máy để có độ mặn $30 \%$, để lắng 48 giờ, phần nước trong phía trên được lấy và lọc qua lưới lọc có mắt lưới là $0,4 \mu \mathrm{m}$ để sử dụng cho thí nghiệm.

Chuẩn bị Artemia nauplii: ấp nở trứng bào xác Artemia ở mật độ $1 \mathrm{~g} / \mathrm{L}$, điều kiện ấp nở gồm độ mặn: $30 \%$, nhiệt độ: $28-30^{\circ} \mathrm{C}$, chiếu sáng và sục khí liên tục, thời gian ấp nở là 20-24 giờ. Âu trùng sau khi nở được sử dụng ngay để bố trí thí nghiệm.

\subsection{Bố trí thí nghiệm}

2.2.1. Thí nghiệm được bố trí ở môi trường ngoài trời với không gian mở có mái che bằng tôn trong, sủ dụng các bể nhựa 60 L với thể tích nước nuôi là $40 \mathrm{~L}$ với 2 mô hình nuôi (có và không có ưng dụng biofloc) ở môi truờng nuôi nước muối và nước ót pha. Tổ hợp của hai nhân tố thí nghiệm gồm 4 nghiệm thức (NT):

NT1: Nước biển (nước ót pha=đối chứng, không biofloc (NB- NBF)

NT2: Nước muối, không biofloc (NM-NBF)

NT3: Nước biển, biofloc (NB- BF)

NT4: Nước muối, biofloc (NM-BF)

Mỗi nghiệm thức gồm 3 lần lặp lại, mật độ thả nuôi là 500 con/L (Coutteau et al., 1990) ở độ mặn 30\%o (Toi et al., 2013), thức ăn được sử dụng trong thí nghiệm là tảo tươi Chaetoceros sp. và thức ăn chế biến dành cho Artemia. Hai ngày đầu, lượng tảo cung cấp cho Artemia dựa theo bảng thức ăn chuẩn của Coutteau et al. (1992). Sau đó, Artemia được 
cho ăn thức ăn chế biến (protein $30 \%$ và $9 \%$ lipid) trong suốt quá trình nuôi. Thức ăn Artemia được ngâm trong nước có cùng độ mặn với bể nuôi khoảng 15 phút, sau đó dung dịch được lắc đều và lọc qua lưới $50 \mu \mathrm{m}$ trước khi cho ăn. Artemia được cho ăn 4 lần/ngày, với liều lượng theo chế độ cho ăn thỏa mãn, dựa vào bảng thức ăn cho Artemia theo Nguyễn Văn Hòa (1993) có điều chỉnh cho phù hợp dựa trên việc quan sát ống tiêu hóa của Artemia và tình trạng sức khỏe bể nuôi hằng ngày. Mật rỉ đường $(\mathrm{C}=40 \%)$ được sử dụng như nguồn carbon hữu cơ để điều chỉnh tỷ lệ $\mathrm{C} / \mathrm{N}=5$ (Panigrahiet al., 2018) theo từng nghiệm thức có ứng dụng biofloc. Hàm lượng rỉ đường $(38 \% \mathrm{C})$, được tính toán và bổ sung theo hàm lượng TAN (tổng đạm ammonia) đo được trong bể nuôi bắt đầu từ ngày nuôi thứ 5 và sau đó định kỳmỗi 3 ngày cho tới khi kết thúc thí nghiệm.

Việc thay nước được thực hiện vào ngày 14 của thí nghiệm. Sau đó tùy thuộc vào chất lượng nước của từng bể nuôi để thay nước với tỷ lệ từ 20 đến $30 \%$ ở các nghiệm thức bình thường, không thay nước đối với môitrường nuôi có ứng dụng biofloc. Các bể nuôi được áp dụng cách thức nuôi theo mẻ, khi Artemia bắt đầu sinh sản (xuất hiện nhiều thế hệ trong bể nuôi, 4 tuần) và quan sát thấy sinh lượng nhiều thì kết thúc mẻ nuôi để tránh mật độ quá cao quần thể nhanh bị suy thoái.

\subsection{Thu thập số liệu}

\section{Chỉ tiêu môi trường}

Nhiệt độ, $\mathrm{pH}$ được theo dõi hàng ngày vào 7 giờ, 14 giờ. Hàm lượng TAN $\left(\mathrm{NH}_{3} / \mathrm{NH}_{4}{ }^{+}\right)$và $\mathrm{NO}_{2}{ }^{-}$được xác định 3 ngày/lần bằng bộ test kit sera của Đức.

\section{Chỉ tiêu sinh trưởng}

Tỷ lệ sống của Artemia được xác định vào ngày nuôi thứ 7 và 14 sau khi bố trí thí nghiệm bằng phương pháp định lượng bằng cách đếm các cá thể còn sống tại những vị trí khác nhau trong bể nuôi trong thể tích $50 \mathrm{~mL}$ nước mẫu. Được tính theo công thức:

$$
\mathrm{S}(\%)=\mathrm{N}_{\mathrm{t}} / \mathrm{N}_{0} \times 100
$$

Trong đó: $\mathrm{N}_{\mathrm{t}}$ là mật độ cá thể thu vào thời điểm thu mẫu, $\mathrm{N}_{0}$ là mật độ thả ban đầu.

Chiều dài Artemia được xác định bằng cách bắt ngẫu nhiên 30 con, sau đó tiến hành đo dưới kính hiển vi chuyên dùng có thước đo. Chiều dài được xác định theo công thức :

$$
\mathrm{L}(\mathrm{mm})=\mathrm{A} / 10 \times 1 \gamma
$$

Trong đó: L là chiều dài Artemia $(\mathrm{mm}) ; \mathrm{A}$ là số vạch đo được; $\gamma$ : độ phóng đại.

Sức sinh sản: số trứng hoặc nauplii trong túi ấp của con cái, được xác định từ 30 con cái thu ngẫu nhiên trong một nghiệm thức, kể từ khi $100 \%$ cá thể cái mang trứng.

Phương thức sinh sản: phần trăm con cái mang trứng đẻ trứng bào xác (cyst) hoặc con non (nauplii) trên tổng số con cái, được xác định từ 30 con cái thu ngẫu nhiên trong một nghiệm thức.

Tỷ lệ con cái tham gia sinh sản: phần trăm con cái có sinh sản trên tổng số con được bắt ra, được xác định từ 30 con cái thu ngẫu nhiên trong một nghiệm thức.

Năng suất sinh khối $\operatorname{Artemia}(\mathrm{g} / \mathrm{L})$ : thu toàn bộ sinh khối Artemia trong bể khi kết thúc thí nghiệm tính năng suất theo khối lượng tươi.

\section{Hiệu quả kinh tế:}

FCR (hệ số thức ăn) = tổng lượng thức ăn/tổng lượng sinh khối thu

Giá thành cơ bản = tổng các chi phí chính bao gồm thức ăn (tảo+thức ăn chế biến) + nước nuôi tính cho $1 \mathrm{~kg}$ sinh khối tươi

\subsection{Phương pháp xử lý số liệu}

Số liệu được xử lý với bảng tính Excel và sử dụng phần mềm Statistica 7.0 với phương pháp phân tích ANOVA hai nhân tố để tìm ảnh hưởng tương tác giữa mô hình nuôi và nguồn nước mặn, và so sánh độ sai biệt có ý nghĩa thổng kê giữa các nghiệm thức ở mức $\mathrm{p}<0,05$ bằng phép thử Tukey.

\section{KẾT QUẢ VÀ THẢO LUẬN}

\subsection{Các yếu tố môi trường}

Thí nghiệm được bố trí ngoài trời với không gian mở có mái che nên ảnh hưởng chủ yếu do sự thay đổi thời tiết trong quá trình nuôi. Nhiệt độ buổi sáng (7h) được ghi nhận là $28,4-28,5^{\circ} \mathrm{C}$ và buổi chiều (2h) là $31,2-31,4^{\circ} \mathrm{C}$, trong khi $\mathrm{pH}$ là $7,8-8,3$. Biên độ nhiệt và $\mathrm{pH}$ này là phù hợp cho sự tăng trưởng và phát triển của Artemia. Theo nghiên cứu của Delos Santos et al. (1980) và Nguyễn Văn Hòa và $c t v$. (2007) thì điều kiện nhiệt độ cho sự phát triển tốt của Artemia là $22-35^{\circ} \mathrm{Cvà} \mathrm{pH}$ thích hợp là 7,0 - 9,0. 


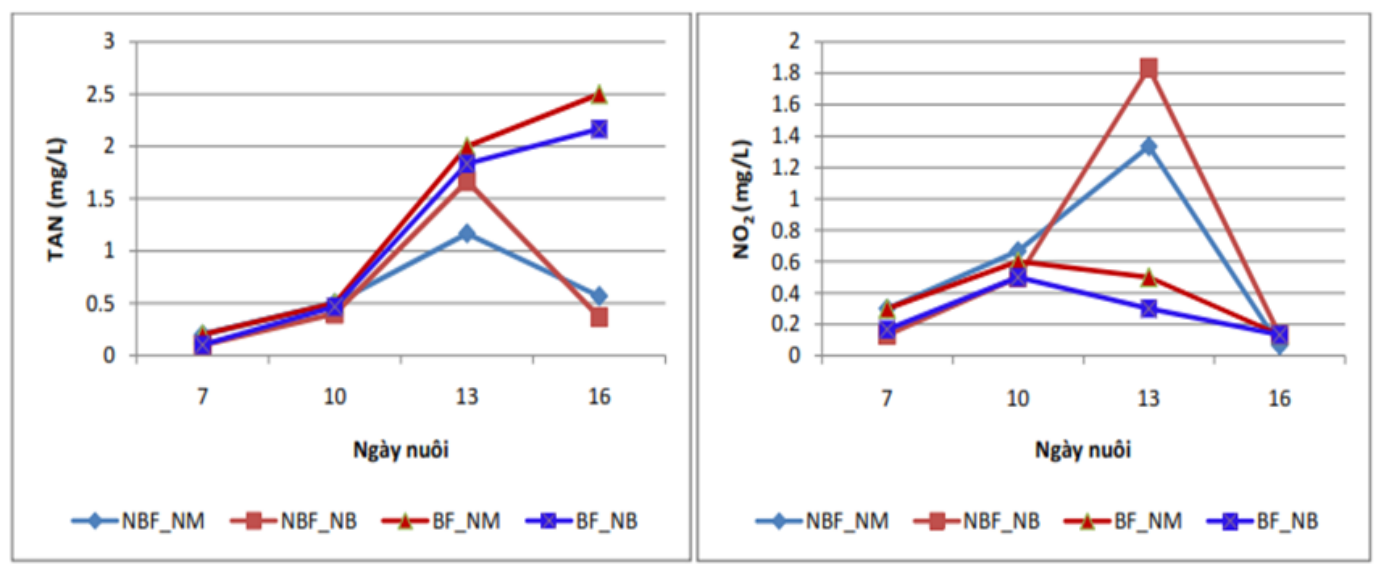

Hình 1. Biến động hàm lượng TAN (trái) và NO2- (phải) trong thời gian nuôi

Hàm lượng TAN trong thí nghiệm dao động từ $0,1-2,5 \mathrm{mg} / \mathrm{L}$ có xu hướng tăng dần theo thời gian thí nghiệm cho tới tuần thứ 2 ở tất cả các nghiệm thức. Sau đó giảm ở các $\mathrm{NT}$ nuôi bình thường và tiếp tục tăng ở các NT ứng dụng biofloc. $\mathrm{NO}_{2}{ }^{-}$dao động từ $0,1-1,6 \mathrm{mg} / \mathrm{L}$, ở các nghiệm thức nuôi bình thường cũng có cùng khuynh hướng với biến động TAN nhưng ở các $\mathrm{NT}$ biofloc thì $\mathrm{NO}_{2}$ chỉ tăng ở tuần đầu sau đó có khuynh hướng giảm cho tới cuối thí nghiệm (Hình 1 ). Sự biến động TAN và $\mathrm{NO}_{2}$ ở các NT là do ảnh hưởng của quá trình thay $20 \%$ nước vào cuối tuần nuôi thứ 2 ở các NT nuôi bình thường trong khi không thay nước ở các NT biofloc. Việc duy trì $\mathrm{NO}_{2}^{-}$khá ổn định ở mức thấp (dưới $0,6 \mathrm{mg} / \mathrm{L}$ )ở các NT biofloc trong suốt quá trình nuôi chứng tỏ có sự hoạt động tích cực của các vi khuẩn trong việc chuyển hóa nitrogen. Mặc dù vậy, Artemia là loài có khả năng chịu đựng hàm lượng TAN và $\mathrm{NO}_{2}^{-}$khá cao. Theo Dhont and Lavens (1996), Artemia có khả năng chịu đựng hàm lượng TAN và $\mathrm{NO}_{2}{ }^{-}$rất cao, $\mathrm{LC}_{50}$ (nồng độ gây chết $50 \%$ sinh vật) của hàm lượng $\mathrm{TAN}$ và hàm lượng $\mathrm{NO}_{2}$ đối với Artemia trong 24 giờ lần lượt là $100 \mathrm{mg} / \mathrm{L}$ và $320 \mathrm{mg} / \mathrm{L}$. Hari et al. (2006) cho rằng việc bổ

Bảng 1. Tỷ lệ sống và chiều dài Artemia vào ngày 7 và ngày 14

\begin{tabular}{lcccr}
\hline \multirow{2}{*}{ NT } & \multicolumn{2}{c}{ Tỷ lệ sống (\%) } & \multicolumn{2}{c}{ Chiều dài $(\mathbf{m m})$} \\
\cline { 2 - 5 } & Ngày 7 & Ngày 14 & Ngày 7 & Ngày 14 \\
\hline NB-NBF & $93,0 \pm 3,5^{\mathrm{c}}$ & $85,0 \pm 1,0^{\mathrm{a}}$ & $3,68 \pm 0,13^{\mathrm{a}}$ & $6,30 \pm 0,43^{\mathrm{a}}$ \\
NM-NBF & $86,3 \pm 2,5^{\mathrm{ab}}$ & $82,3 \pm 2,1^{\mathrm{a}}$ & $3,67 \pm 0,06^{\mathrm{a}}$ & $5,80 \pm 0,19^{\mathrm{a}}$ \\
NB-BF & $90,0 \pm 1,0^{\mathrm{bc}}$ & $82,3 \pm 5,1^{\mathrm{a}}$ & $4,00 \pm 0,17^{\mathrm{b}}$ & $6,73 \pm 0,44^{\mathrm{a}}$ \\
NM-BF & $82,7 \pm 1,5^{\mathrm{a}}$ & $78,7 \pm 1,8^{\mathrm{a}}$ & $4,00 \pm 0,20^{\mathrm{b}}$ & $6,30 \pm 0,54^{\mathrm{a}}$ \\
\hline
\end{tabular}

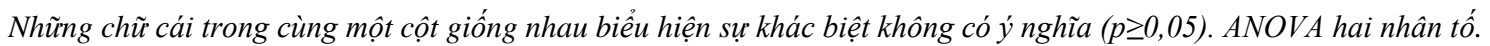

Kết quả ở Bảng 1 cũng cho thấy TLS ở 2 hệ thống nuôi (có và không có biofloc) vào ngày 14 không có sự chênh lệch đáng kể và không bị ảnh hưởng bởi hệ thống nuôi cũng như môi trường nuôi sung carbohydrate đã làm giảm sự tích tụ $\mathrm{TAN}$ và $\mathrm{NO}_{2}^{-}$trong nước, do đó hàm lượng $\mathrm{TAN}$ và $\mathrm{NO}_{2}{ }^{-}$ trong thí nghiệm hiện tại đều nằm trong khoảng thích hợp cho Artemia.

\subsection{Tỷ lệ sống và tăng trưởng của Artemia}

\subsubsection{Tỷ lệ sống}

Kết quả tỷ lệ sống (TLS) qua hai tuần nuôi được trình bày trong Bảng 1 . Tỷ lệ sống 7 ngày đầu dao động trong khoảng từ $83 \%$ - 93\%, đến ngày thứ 14 , tỷ lệ sống có xu hướng giảm nhưng không đáng kể (79-85\%). Kết quả này so với thí nghiệm nuôi trong phòng ở quy mô nhỏ $4 \mathrm{~L}$ (Van and Toi, 2019) có cùng NT thì thấp hơn từ $4-5 \%$, tuy nhiên vì nuôi trong bể lớn $(60 \mathrm{~L})$ và môi trường hở nên sự hao hụt này là ở mức chấp nhận. Kết quả cũng cho thấy môi trường nuôi và cả hệ thống nuôi rõ ràng tác động đến TLS vào ngày 7 (Bảng 1 và $2 ; \mathrm{p}<0,05)$ ở các NT nuôi bằng nước ót pha $(\mathrm{NB})$ thì Artemia có TLS (90$93 \%$ ) tốt hơn các NT nuôi bằng nước muối 82-86\%) và nuôi với $\mathrm{BF}$ thì có tỷ lệ sống thấp hơn so với $\mathrm{NBF}$ (86\% so với $90 \% ; p<0,05)$ $(\mathrm{p}>0,05)$ và các NT biofloc luôn có TLS thấp hơn NBF. Kết quả tỷ lệ sống này ngược với kết quả thu được ở trong phòng là TLS ngày 14 ở các NT bioflocs là cao hơn NBF (86,5\% so với 83,5\%; Van 
and Toi, 2019). Sự khác biệt này có thể do môi trường nuôi hở đã kích thích vi khuẩn phát triển mạnh hơn, điều này dễ nhận thấy màu nước của bể nuôi có màu trắng đậm hơn so với khi được nuôi trong phòng kín ở các NT có biofloc làm ảnh hưởng tới TLS bởi vì vi khuẩn vừa có thể là thức ăn nhưng ở mật độ quá cao chúng cũng có thể gây hại cho Artemia (Toi et al., 2013).

Bảng 2. Tác động của các nhân tố thí nghiệm lên các chỉ tiêu theo dõi ở Artemia (giá trị p)

\begin{tabular}{lrrr}
\hline \multirow{2}{*}{ Chỉ tiêu } & \multicolumn{3}{c}{ Nhân tố tác động } \\
\cline { 2 - 4 } & Hệ thống nuôi (HT) & Môi trường nuôi (MT) & Tương tác (HTx MT) \\
\hline Tỷ lệ sống ngày 7 & $0,0415^{*}$ & $0,0009^{* * *}$ & 0,8144 \\
Tỷ lề sống ngày 14 & 0,0884 & 0,0884 & 0,7672 \\
Chiều dài ngày 7 & $0,0060^{* *}$ & 0,9431 & 0,8308 \\
Chiều dài ngày 14 & 0,0778 & 0,0798 & 0,8164 \\
\hline
\end{tabular}

(***: khác biệt có ý nghĩa $p<0,001 ; * *: p<0,01$ và *: $p<0,05)$

\subsubsection{Chiều dài của Artemia}

Chiều dài của Artemia ở ngày nuôi thứ 7 (Bảng 1) giữa các nghiệm thức có sự khác biệt có ý nghĩa thống kê $(\mathrm{p}<0,05)$, đối với nghiệm thức $\mathrm{NBF}$ chiều dài dao động trung bình trong khoảng 3,67 - 3,68 $\mathrm{mm}$. Khi có bổ sung rỉ đường $(\mathrm{BF})$ thì chiều dài của Artemia đạt khoảng $4 \mathrm{~mm}$, tăng lên khác biệt có ý nghĩa giữa các NT (Bảng 1 ). Đến ngày thứ 14 , chiều dài của Artemia có tăng nhưng vẫn theo khuynh hướng của ngày 7 , dao động trong khoảng 5,8 - 6,73 $\mathrm{mm}$. Ở các nghiệm thức không bổ sung rỉ đường, chiều dài trung bình của Artemia kém hơn từ 0,4$0,5 \mathrm{~mm} / \mathrm{cá}$ thể so với các NT có bổ sung rỉ đường nhưng sự khác biệt này không có ý nghĩa thống kê ( $p>0,05)$. Mặt khác, Artemia nuôi bằng nước ót pha cũng có chiều dài lớn hơn nước muối từ $0,4-0,5 \mathrm{~mm}$. So với kết quả chiều dài khi nuôi trong phòng ở quy mô nhỏ (Van and Toi, 2019) ở cùng NT thí nghiệm thì khi nuôi ngoài trời Artemia đồng cỡ và tăng trưởng tốt hơn trong phòng $(5,8-6,73 \mathrm{~mm}$ so với 5,5$6,0 \mathrm{~mm})$.

Kết quả thống kê trong Bảng 2 cũng cho thấy việc có và không có ứng dụng biofloc trong môi trường nuôi và việc sử dụng nước muối thay thế nước ót pha hoàn toàn không có tác động đáng kể đến chiều dài và TLS của Artemia sau 7 ngày nuôi. Điều này có thể là do sự thiếu hụt khoáng vi lượng trong môi trường nước muối, tương tự, Kolev et al. (2013) cho rằng muối biển mặc dù có các muối đa lượng tương tự với nước biển nhưng nó thiếu rất nhiều các nguyên tố vi lượng so với nước biển, do vậy đã ảnh hưởng tới sự phát triển của Artemia ở tuần tuổi đầu nhưng sau đó chúng đã thích nghi với môi trường sống và được bổ sung các khoáng này từ nguồn thức ăn, vi khuẩn,...nên đã không còn sự khác biệt giữa các nghiệm thức.

\subsection{Các chỉ tiêu sinh sản của Artemia}

Trong thí nghiệm này, Artemia bắt đầu tham gia sinh sản rất sớm tương đồng với thời gian thành thục khi nuôi ở ngoài đồng (Nguyễn Văn Hòa và $c t v$., 2007), vào ngày thứ $7-8$, đã quan sát thấy có xuất hiện bắt cặp ở các NT NBF và muộn hơn 2-3 ngày đối với các $\mathrm{NT} B \mathrm{BF}$, quá trình sinh sản kéo dài khi đến hết thí nghiệm. Trong các tuần thu mẫu ở tất cả các NT, $100 \%$ con cái đều tham gia sinh sản khác với khi nuôi trong phòng (Van and Toi, 2019) chỉ có NT NB-NBF có TLS 100\% còn lại chỉ khoảng 40$80 \%$. Sự khác biệt này có thể do thí nghiệm này làm ở không gian mở dẫn đến nhiều biến động về môi trường nuôi cũng như nguồn thức ăn từ tự nhiên (tảo, vi khuẩn phát triển ngẫu nhiên trong bể nuôi) làm cho Artemia có nhiều nguồn dinh dưỡng hơn và quần thể phát triển cũng tốt hơn. Sức sinh sản của Artemia ở các nghiệm thức NBF dao động rất ít 4850 phôi/con cái, cao hơn so với các NT biofloc (BF) là từ 42-48 phôi/con cái, tuy nhiên sự chênh lệch này không có ý nghĩa thống kê (p>0,05)(Bảng 3) ngoại trừ NT BF-100 (42 phôi) khác biệt có ý nghĩa $(\mathrm{p}<0,05)$ với $\mathrm{NBF}-100$ (50 phôi). Kết quả này là thấp hơn so với thí nghiệm trong phòng (50-70 phôi/con cái) có lẽ là do Artemia trong thí nghiệm này sinh sản sớm dẫn đến mật độ tăng cao trong bể nuôi dẫn đến ảnh hưởng tới sức sinh sản của con cái.

Bảng 3. Các chỉ tiêu sinh sản

\begin{tabular}{lrrr}
\hline Nghiệm thức & SSS (phôi/con cái) & Tỷ lệ sinh con (\%) & Tỷ lệ sinh trứng (\%) \\
\hline NB-NBF & $48,1 \pm 0,7^{\mathrm{ab}}$ & $41,0 \pm 1,7^{\mathrm{b}}$ & $59,0 \pm 1,7^{\mathrm{a}}$ \\
NM-NBF & $50,0 \pm 2,0^{\mathrm{b}}$ & $41,8 \pm 11,5^{\mathrm{b}}$ & $58,2 \pm 11,5^{\mathrm{a}}$ \\
NB-BF & $48,3 \pm 4,6^{\mathrm{ab}}$ & $15,0 \pm 2,0^{\mathrm{a}}$ & $75,0 \pm 2,0^{\mathrm{b}}$ \\
NM-BF & $42,0 \pm 1,0^{\mathrm{a}}$ & $41,0 \pm 1,0^{\mathrm{b}}$ & $59,0 \pm 1,0^{\mathrm{a}}$ \\
\hline
\end{tabular}

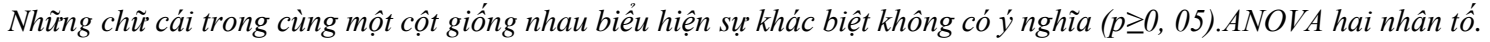


Tỷ lệ sinh con hoặc sinh trứng bào xác (phương thức sinh sản; Bảng 3 ) cho thấy tỷ lệ sinh con thấp và trứng cao ở NT BF-0 (chỉ có $15 \%$ đẻ con) và khác biệt có ý nghĩa với các NT khác (biến động từ 41$42 \%$ ). Kết quả phân tích thống kê từ Bảng 4 chỉ ra rằng tỷ lệ sinh con bị ảnh hưởng bởi cả môi trường nuôi, hệ thống nuôi cũng như sự tương tác giữa chúng. Việc tăng tỷ lệ sinh trứng có lẽ do môi trường ở NB-BF (nước biển $100 \%$ ) có nhiều cơ hội để vi khuẩn phát triển hơn so với NM-BF do nước muối nên bị thiếu vi lượng (Drehval et al., 2003), vì thế vi khuẩn tăng quá mức làm ảnh hưởng tới phương thức sinh sản của chúng (báo hiệu môi trường không thuận lợi) mà Browne et al. (1984) và Van Stappen (2002) đều cho rằng khi môi trường không thuận lợi Artemia có khuynh hướng sinh trứng và ngược lại. Hơn nữa, Abdel-Azizet al. (2016) còn cho rằng có mối liên quan giữa các chất dinh dưỡng bị giới hạn và tăng trưởng của vi khuẩn, đồng thời sự phát triển và tính đa dạng của vi khuẩn cũng thay đổi theo các yếu tố môi trường sống, cụ thể trong thí nghiệm này quan sát thấy ở NT NB-BF nước nuôi có màu nước đục hơn các NT khác. Tuy nhiên cũng cần có thêm nghiên cứu chuyên sâu về vi khuẩn để khẳng định.

Bảng 4. Tác động của các nhân tố thí nghiệm lên các chỉ tiêu theo dõi ở Artemia (giá trị p)

\begin{tabular}{lrrr}
\hline \multirow{2}{*}{ Chỉ tiêu } & \multicolumn{3}{c}{ Nhân tố tác động } \\
\cline { 2 - 4 } & Hệ thống nuôi (HT) & Môi trường nuôi (MT) & Tương tác (HTx MT) \\
\hline Sức sinh sản & 0,0527 & 0,1087 & $0,0436^{*}$ \\
Phương thức sinh sản & $0,0047^{* *}$ & $0,0047^{* *}$ & $0,0062^{* *}$ \\
Sinh khối & $0,0072^{* *}$ & 0,1016 & 0,0775 \\
\hline
\end{tabular}

(***: khác biệt có ý nghĩa $p<0,001 ; * *: p<0,01$ và *: $p<0,05)$

Kết quả thống kê (Bảng 4) cũng cho thấy trong khi sức sinh sản hầu như không bị ảnh hưởng ( $p>0,05$ ) bởi hệ thống nuôi (có hoặc không biofloc) hoặc môi trường nuôi (nước biển hoặc nước muối) nhưng bị ảnh hưởng từ sự tương tác giữa chúng $(\mathrm{p}<0,05)$, tuy nhiên phương thức sinh sản lại bị tác động cả từ hai nhân tố thí nghiệm cũng như sự tương tác giữa chúng

\subsection{Sinh khối Artemia}

Hình 2 cho thấy sau 20 ngày nuôi năng suất sinh khối Artemia đạt cao nhất ở các NT nuôi trong hệ thống biofloc $(\mathrm{BF})$ với trung bình $3,52 \pm 0,08 \mathrm{~g} / \mathrm{L}$ khác biệt có ý nghĩa thống kê $(\mathrm{p}<0,05)$ so với hệ thống nuôi không biofloc NBF $(3,24 \pm 0,23 \mathrm{~g} / \mathrm{L})$. Ở các NT nuôi bằng nước muối, lượng sinh khối thu gần như tương tự với nuôi ở nước biển $(3,45 \pm 0,18$ $\mathrm{g} / \mathrm{L}$ và $3,30 \pm 0,25 \mathrm{~g} / \mathrm{L}$ ). Tương tự như sức sinh sản, sinh khối Artemiachỉ bị ảnh hưởng bởi hệ thống nuôi vì thế có thể nói sự tăng thêm nguồn thức ăn từ vi khuẩn dị dưỡng thông qua biofloc đã thúc đẩy sự gia tăng về sinh khối thu được trong các NT BF. Kết quả cho thấy lượng sinh khối thu thấp nhất ở NB-NBF là thấp nhất tuy nhiên cũng không có khác biệt so với NM-NBF do ở NM-NBF có sự biến động cao giữa các lần lặp lại có lẽ là do môi trường nuôi không ổn định, đây có thể là do không có sự chuyển hóa đạm từ chất thải sang thành lập tế bào vi khuẩn như các nghiệm thức có ứng dụng công nghệ biofloc. Ngoài ra, TLS cao $(93 \%)$ và chiều dài khá tương đồng với các NT khác $(6,3 \mathrm{~mm})$ ở NB-NBF nhưng sinh khối thu lại thấp có thể là do các thông số này được thu vào ngày 14 trong khi sinh khối được thu vào ngày 20. Artemia có chu kỳ sinh sản rất ngắn, ở $30 \%$ chu kỳ sinh sản của chúng chỉ hoảng 2-3 ngày (Nguyễn Thị Hồng Vân và Huỳnh Thanh Tới, 2017) và ở trong môi trường nước biển chúng sinh sản lại sớm hơn so với các NT biofloc và nước muối như đã đề cập ở phần sinh sản, do vậy sự bổ sung quần thể quá nhanh làm mật độ trong bể nuôi tăng cao cộng với sự phát triển của vi khuẩn đã làm quần thể mau suy thoái (con trưởng thành bị chết) dẫn đến lượng sinh khối thu giảm đi. 


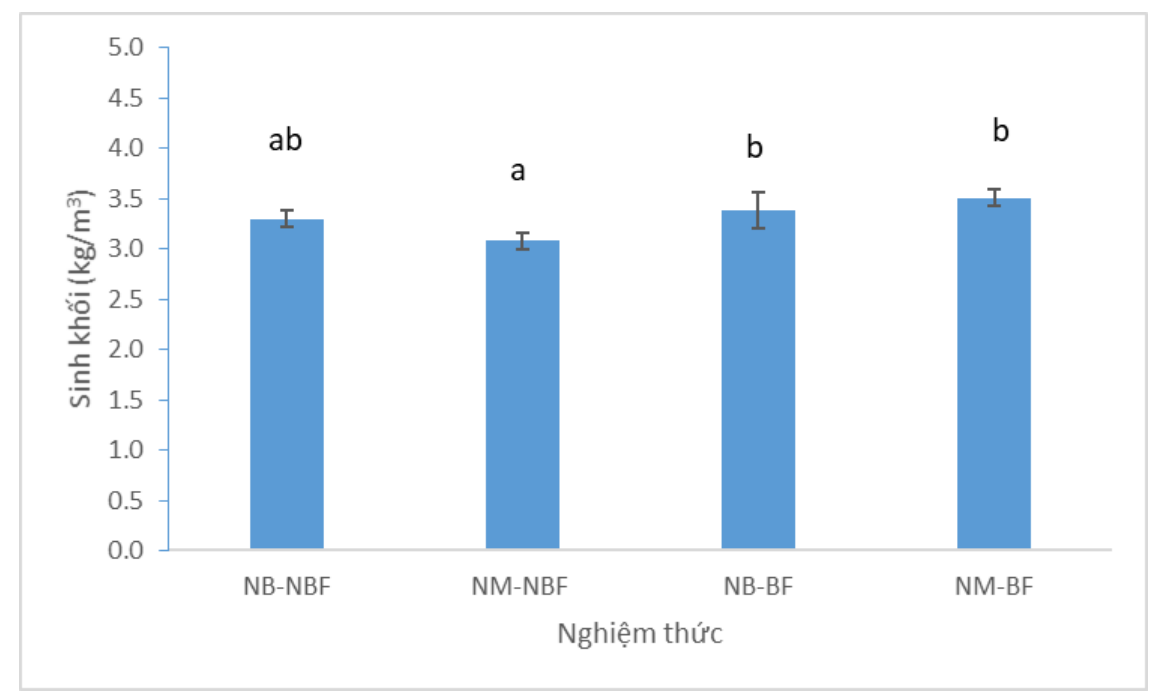

Hình 2. Sinh khối Artemia sau 20 ngày nuôi

Kết quả sinh khối Artemiathu được trong thí nghiệm này khá tương đồng với thí nghiệm trong phòng có cùng NT của Van and Toi (2019) nhưng số ngày nuôi ít hơn (20 ngày so với 28 ngày) cho thấy nuôi sinh khối ngoài không gian mở là tốt hơn so với nuôi kín trong phòng. So với các thử nghiệm nuôi đại trà trước đây cũng với nước ót pha ở độ mặn $30 \%$ cùng cùng thể tích và mật độ, thì kết quả này cao hơn nhiều so với năng suất được báo cáo của Lê Văn Thông và $c t v$. (2018) là $1,08-1,45 \mathrm{~g} / \mathrm{L}$ tùy phương thức thu hoạch.

Bảng 5. Một số chỉ tiêu đánh giá hiệu quả nuôi sinh khối Artemia (tổng lượng sinh khối của 03 bể nuôi của mỗi nghiệm thức) trong 20 ngày

\begin{tabular}{lrrrr}
\hline \multirow{2}{*}{ Chỉ tiêu đánh giá } & \multicolumn{3}{c}{ Nghiệm thức (NT) } \\
\cline { 2 - 5 } & NB-NBF & NB-BF & NM-NBF & NM-BF \\
\hline Trung bình sinh khối thu/ngày $(\mathrm{g} / \mathrm{L})$ & 18,34 & 19,41 & 19,21 & 20,46 \\
Tổng lượng sinh khối thu $(\mathrm{g})$ & 367 & 388 & 384 & 409 \\
Tồng lượng thức ăn chế biến $(\mathrm{g})$ & 554 & 509 & 554 & 509 \\
Tồng lượng tảo sử dụng $(\mathrm{L})$ & 1,5 & 1,5 & 1,5 & 1,5 \\
FCR & 1,51 & 1,31 & 1,44 & 1,24 \\
\hline Chi phí cơ bản (tính trên kg sinh khối tươi thu được) & & & \\
\hline - Tảo & 20,436 & 19,330 & 19,531 & 18,338 \\
- Nước & 78,500 & 61,829 & 22,484 & 17,595 \\
- Thức ăn & 45,274 & 39,364 & 43,225 & 37,340 \\
Giá thành (đ/kg SK tươi) & 144,210 & 120,523 & 85,240 & 73,273 \\
\hline
\end{tabular}

(Ghi chú: Tảo được tính với giá nuôi cấy đại trà trong bọc (10.000 đ/L); nuoóc ót: 400.000 đ/m³); muối hột: 2.000 đ/kg; thưc ăn Artemia: 30.000 đ/kg)

Với sinh lượng thu được từ $18-20 \mathrm{~g} /$ ngày nuôi (Bảng 5) thì hệ số thức ăn vào khoảng 1,28 trong hệ thống $\mathrm{BF}$ và khoảng 1,48 khi nuôi bình thường như vậy việc ứng dụng biofloc đã tiết giảm được khoảng $14 \%$ lượng thức ăn chế biến. Hơn nữa, các NT có ứng dụng BF không thay nước do vậy cũng tiết kiệm được một lượng nước từ 20-30\% kể từ ngày 14 trở đi và công để thay và bù nước trong bể nuôi.

Xét về khía cạnh giá thành sinh khối cơ bản (không tính phí chăm sóc và điện cho sục khí) thì việc sử dụng nước muối biển có thể giảm được khoảng 70\% chi phí nước biển (là chi phí chủ yếu trong cơ cấu giá thành khi nuôi sinh khối bằng nước ót pha (Bảng 5) dẫn đến giá sinh khối giảm đi 36\% $(85, .13 \mathrm{~d} / \mathrm{kg}$ so với $132.367 \mathrm{~d} / \mathrm{kg})$ và điều quan trọng là chủ động được nguồn nước nuôi và dễ ứng dụng cho các trại giống xa biển. Thêm vào đó ứng dụng biofloc cũng giảm đi $13,4 \%$ chi phí thức ăn chế biến (38.340 đ/kg so với 44.250 đ $/ \mathrm{kg})$. Từ kết quả giá thành ở Bảng 5 cho thấy khi ứng dụng biofloc thì giá thành sinh khối giảm khoảng $17 \%$ với nước biển (120.000 so với 144.000 đ/kg) và $14 \%$ so với nuôi 
bằng nước muối (73.000đ so với 85.000 đ/kg). Mặc dù giá thành để sản xuất sinh khối bằng nước muối từ 73.000- $85.000 \mathrm{~d} / \mathrm{kg}$ là có thể chấp nhận được khi sinh khối đông lạnh có giá bán thấp nhất là 50.000 đ/kg chưa tính phí vận chuyển nhưng nên có nghiên cứu thêm về giá trị dinh dưỡng của loại sinh khối này.

\section{KẾT LUẬN VÀ ĐỀ XUẤT}

\subsection{Kết luận}

Tỷ lệ sống và chiều dài của Artemia không bị ảnh hưởng bởi việc ứng dụng biofloc cũng như việc sử dụng nước muối hay nước ót pha sau ngày 7 nuôi.

Sức sinh sản và lượng sinh khối thu bị ảnh hưởng chỉ bởi việc ứng dụng biofloc, trong hệ thống biofloc con cái có sức sinh sản kém hơn ở hệ thống bình thường nhưng sinh khối thu lại cao và ổn định hơn.

Phương thức sinh sản bị tác động bởi cả hai nhân tố thí nghiệm và có khuynh hướng sinh trứng ở các bể nuôi trong hệ thống biofloc với nước ót pha.

Sinh khối thu được ở các nghiệm thức có bổ sung rỉ đường $(\mathrm{BF})$ cao hơn so với các nghiệm thức đối chứng $(\mathrm{NBF})$ khoảng $8,6 \%$ và còn tiết giảm được $14 \%$ lượng thức ăn đưa vào.

Việc sử dụng nước muối biển nuôi sinh khối Artemia làm giảm $36 \%$ giá thành sinh khối khi nuôi bình thường và ứng dụng biofloc làm giảm giá thành khoảng $18 \%$ khi nuôi với nước biển và $14 \%$ khi nuôi bằng nước muối.

\section{2. Đề xuất}

Có thể ứng dụng nuôi sinh khối Artemia bằng nước muối và ứng dụng biofloc trong các trại tôm cá giống tuy nhiên cần có thêm nghiên cứu về hệ vi khuẩn và dinh dưỡng của sinh khối thu

\section{TÀI LIỆU THAM KHẢO}

Abdel-Aziz, S., Gupta, V., Sukmawati, D. \& Fadel, M. (2016). Role of nutrient in microbial developments and microbial metabolic diversity In V. Kumar Gupta, S. Zeilinger, E. Ferreira Filho, M. Carmen Durán-Dominguez-de-Bazu \& D. Purchase (Ed.), Microbial Applications (pp. 151-176). Berlin, Boston: De Gruyter. https://doi.org/10.1515/9783110412789-009

Browne, R. A., Sallee, S. E., Grosch, D. S., Segerti, W. O., \& Purser, S.M. (1984). Partitioning genetic and environmental components of reproduction and lifespan in Artemia. Ecology, 65(3), 949-960

Coutteau, P., Brendonck, L., Lavens, P., \& Sorgeloos, P. (1992). The use of manipulated baker's yeast as an algal substitute for the laboratory culture of Anostraca. Hydrobiologia. 234(1), 25-32

De los Santos, C. jr., Sorgeloos, P., Lavina, E., \& Bernardino, A. (1980). Successful inoculation of Artemia and production of cysts in man-made Salterns in the Philippines. (pp. 159-163). In Persoone, G., Sorgeloos, P., Roels, 0., \& Jaspers, E. (Eds.) The brine shrimp Artemia Vol. 3 Ecology, Culturing, Use in $~ q u a c u l t u r e .$. Universa Press, Wetteren, Belgmm. 456 p.

Dhont, J., \& Lavens, P. (1996). Tank production anduse of on grown Artemia (pp.164-194). In Sorgeloos, P., Lavens, P. (Eds.). Manual on the Production and Use of Live Food for Aquaculture. Fisheries Technical Paper No. 361. Food and Agriculture Organization of the United Nations. Rome,

Drehval, O.A., Chervatiuk, N. V., Cherevach, N.V., \& Vinnikov, A.I. (2003). Effect of mineral nutrition sources on the growth and toxin formation of the entomopathogenic bacteria Bacillus thuringiensis. Mikrobiol Z. 65(3),14-20

Hari, B., Kurup, B.M., Varghese, J.T., Schrama, J.W. \& Verdegem, M.C.J., 2006. The effect of carbohydrate addition on water quality and the nitrogen budget in extensive shrimp culture systems. Aquaculture, 252, 248-263

Huỳnh Thanh Tới và Nguyễn Thị Hồng Vân (2017). Ảnh hưởng của tỷ lệ $\mathrm{C} / \mathrm{N}$ và khẩu phần ăn lên sinh trưởng và năng suất sinh khối Artemia franciscana trong điều kiện phòng thí nghiệm. Tạp chi Khoa hoc Truòng Đại hoc Cần Tho, 54, 90-97

Kolev, H., Tyuliev, G., Christov, C., \& Kostov, K. L. (2013). Experimental study of the surface chemical composition of sea salt crystallized during evaporation of seawater under natural conditions. Bulgarian Chemical Communications, 45 (4), 584-591

Lê Quốc Việt, Trần Minh Nhứt, Lý Văn Khánh, Tạ Văn Phương, \& Trần Ngọc Hải (2015). Úng dụng biofloc nuôi tôm thẻ chân trắng (Litopenaeus vannamei) với mật độ khác nhau kết hợp với cá rô phi (Oreochromis niloticus). Tạp chi Khoa học Trương Đại học Cần Tho, 38, 44-52

Lê Quốc Việt, Trần Minh Phú, \& Trần Ngọc Hải (2017). Đánh giá khả năng thay thế thức ăn công nghiệp bằng khoai lang (Ipomoea batatas) trong nuôi tôm thẻ chân trắng (Litopenaeus vannamei) theo công nghệ biofloc. Tap chi Khoa hoc Truoòng Đai học Cần Tho; 48, 27-35

Lê Văn Thông, \& Nguyễn Văn Hòa (2018). Ảnh hưởng của độ mặn, mật độ và phương thức thu hoạch đến năng suất của sinh khối Artemia franciscana nuôi trên bể. Tạp chi Khoa học Truò̀ng Đại hoc Cần Thơ, 54, 129-141. 
Léger, P., Bengtson, D. A., Simpson, S.L., \& Sorgeloos, P. (1986). The use and nutritional value of Artemia as a food soures. Oceanography Marine Boil. Ann. Rev. 24, 521-623.

Nguyễn Thị Hồng Vân, \& Huỳnh Thanh Tới (2017). Ảnh hưởng của độ mặn thấp lên sinh trưởng và sinh sản của Artemia franciscana dòng Vĩnh châu. Tạp chi Khoa hoc Đại hoc Cần Tho. 53b, 41-48.

Nguyễn Thị Hồng Vân, Nguyễn Văn Hòa, Trần Nguyễn Hải Nam, \& Trần Hữu Lễ (2010). Khả năng sử dụng các loại sinh khối khác nhau trong ương nuôi một số loài cá nước ngọt. Tạp chí Khoa học Trường Đại học Cần Tho, 15a, 241-252

Nguyễn Thị Ngọc Anh (2011). Sử dụng sinh khối Artemialàm thức ăn trong ương nuôi các loài thủy sản nước lợ. Tạp chí Khoa hoc Truờng Đại hoc Cần Tho, 19b, 168-178.

Nguyễn Văn Hòa, Nguyễn Thị Hồng Vân, Nguyễn Thị Ngọc Anh, Pham Thị Tuyết Ngân, Huỳnh Thanh Tới \& Trần Hữu Lễ (2007). Artemia nghiên cưu và úng dụng trong nuôi trồng thủy sản. Nhà xuất bản Nông nghiệp.Thành phố Hồ Chí Minh.

Panigrahi, A., Sundaram, M., Chakrapani, S., Rajasekar, S., Syama Dayal, J., \& Chavali, G.
(2018). Effect of carbon and nitrogen ratio (C:N) manipulation on the production performance and immunity of Pacific white shrimp Litopenaeus vannamei (Boone, 1931) in a biofloc-based rearing system. Aquaculture Research, 50, 29-41.

Toi, H.T, Van Hoa N., Bossier P., Sorgeloos P., \& Van Stappen, G. (2013). Promoting of bacteria growth by manipulating carbon/nitrogen ratio and use as microalgae substitution for filter feeders: a demonstration on Artemia culture. Commun. Agric. Appl. Biol. Sci., 78,198-201

Trần Ngọc Hải, Trần Văn Ghẹ, Cao Mỹ Án, \& Lê Quốc Việt (2016). Ảnh hưởng của tỷ lệ C:N khác nhau lên tăng trưởng, tỷ lệ sống và chất lượng của cá rô phi (Oreochromis niloticus) nuôi theo công nghệ biofloc. Tap chí Khoa họ Truòng Đai hoc Cần Tho, 46, 103-110.

Van Stappen, G., 2002. Zoogeography (pp. 171224).. In: Abatzopoulos Th. J. (Eds.), Beardmore, J.A., Clegg, J.S., Sorgeloos, P. Artemia: Basic and Applied Biology. Kluwer Academic Publishers. Dordrecht

Van, N. T. H., \& Toi, H.T. (2019). Use of seasalt for Artemia biomass culture incorporation with biofloc technology. International Journal of Scientific and Research Publication, 9(1), 172-179. 